\title{
Emotions, Stressors, Coping Strategies, and Motivational Factors in Private Higher Education Institutions amid COVID-19 Pandemic
}

\author{
Erick T Baloran ${ }^{1 *}$ and Jenny T Hernan ${ }^{2}$ \\ College of Teacher Education, University of Mindanao - Bansalan College, Bansalan, Philippines
}

Correspondence should be addressed to Erick T Baloran, erickbaloran.research@gmail.com

Received: August 19, 2020; Accepted: September 07, 2020; Published: September 14, 2020

\begin{abstract}
Private school teachers among Higher Education Institutions (HEIs) continue to strive to sustain quality education despite the psychological impact of the COVID-19 crisis. This study aimed to assess the emotions, stressors, coping strategies, and motivational factors of private HEI's teachers in Southern Philippines. Both negative and positive teachers' emotions were observed. Low salary scheme was the primary teachers' stressor. But, teachers utilized helpful strategies to cope with stress. Several motivational factors were seen as significant steps for their institutions to implement and follow. The high level of stressors of teachers during the pandemic influences the emotions towards the community and work situations. As they increasingly practice varied coping strategies and augment motivation to continue to work despite the situation, the better emotional state with lesser adverse feelings they will have. Government support is needed to aid private schools to continue the quality delivery of higher education. It is necessary to address stress-related problems of teachers during the pandemic, and help them strengthen their coping practices and motivation at work.
\end{abstract}

\section{KEYWORDS}

Emotions; Stressors; Coping strategies; Motivational factors; COVID-19 pandemic

\section{INTRODUCTION}

The COVID-19 pandemic has brought significant concerns in various sectors across the globe, primarily affecting Higher Education Institutions (HEIs). The International Association of Universities [1] reported that there are more than 1.5 billion students and youth across countries are affected by school closures. Various recommendations for HEIs are continually suggested to carry on with teaching and learning activities during the socio, economic, cultural, and health crisis. Studies on the impact of COVID-19 pandemic in the Philippines were conducted, which not just clearly revealed strong reactions among tertiary students [2] but also discovered teachers' level of anxiety amid school closures, home quarantine, and community social distancing [3].

In terms of mental and emotional health during a pandemic situation, stress and anxiety-related behaviors of individuals were observed during the COVID-19 crisis. Peoples' anxiety is real due to community susceptibility. Self-isolation caused fear and depression among individuals. It is necessary to enhance media management to improve people's pandemic

Citation: Erick T Baloran, Emotions, Stressors, Coping Strategies, and Motivational Factors in Private Higher Education Institutions amid COVID-19 Pandemic. J Clin Cases Rep 3(S4): 12-18.

2582-0435/@ 2020 The Authors. Published by TRIDHA Scholars. 
understanding and, eventually, public health and emotional well-being. Besides, psychological resources to deal with stress and to control feelings caused by COVID-19 should be of significant concern [4]. Relative to school context, anxiety, or psychological stress brought by COVID-19 caused teachers in the Philippines to have weak confidence to go to social gatherings and utilize public transportation. Teachers felt fear and became more apprehensive about personal cleanliness. However, Filipino teachers' positive outlook amid psychological stress or anxiety was seen [3]. Teachers indeed had to face lifestyle changes during the pandemic situation [5].

Also, the COVID-19 pandemic had resulted in education to change dramatically, with the notable rise of elearning. However, with this sudden shift away from the classroom, educators doubt whether the adoption of online learning will continue to persist post-pandemic, and how such a change would impact the worldwide education market [6]. The study of Baloran [2] emphasized that the Philippines is still challenged with the application of the online-blended learning approach. HEIs should even fill the gaps in providing Information and Communication Technology (ICT) resources and capacities of both teachers and students as they embrace the paradigm shift in pedagogical delivery. With the contexts mentioned above and to get more data on the status of HEIs during the COVID-19 pandemic, this study aimed to assess emotions, stressors, coping strategies, and motivational factors of private school teachers among HEIs in Davao Region, Southern Philippines during the COVID-19 pandemic.

\section{METHOD}

A descriptive-correlational method was used in this study involving private colleges and universities in Region XI (Davao Region), Southern Philippines. An online survey developed through Google forms with an appended consent form was conducted from May 14, 2020 - May
22, 2020, while the Philippines was experiencing the first wave of sustained community transmission and provinces in Davao Region were under general and enhanced community quarantine set by the local governments. The snowball technique was used to determine the teacher respondents who had access to the internet. Survey link was disseminated to private teachers among HEIs via social media with the assistance of the Philippine Association for Teachers and Educators (PAFTE) Region XI. The questions were adapted from the study of Khalid et al. [7] and Baloran [2]. They were modified to suit the purpose of the study. There were a total of 506 private school teachers across the region who responded in the online survey, which set the study's sample size limitation. Data were analyzed using frequency and mean percentage as statistical tools to interpret the teachers' responses. The following range of means with its descriptions was used: 1.00 - 1.79 (Very Low); 1.80 2.59 (Low); 2.60 - 3.39 (Moderate); 3.40 - 4.19 (High); $4.20-5.00$ (Very High).

\section{RESULTS}

Private school teachers among Higher Education Institutions (HEIs) who were involved in this study came from the various provinces in the Davao region, Southern Philippines. Among the 506 teachers who responded in the online survey, $213(42.09 \%)$ were female, 189 (37.35\%) were male, and $104(20.55 \%)$ belonged to the LGBTQ+ group. The mean age of these private school teachers was 38.02 (commonly belong to the Millennial generation). The majority of the teachers were single (263\% or $51.98 \%)$, while the other $243(48.02 \%)$ were married. In terms of employee classification, 273 $(53.95 \%)$ were regular/permanent, and 233 (46.05\%) was probationary. Most of the teacher respondents have 1 year - 5 years of teaching experience (263\% or $51.98 \%$ ), 21 years and above (123\% or $24.31 \%)$, and 6 years - 10 years $(120 \%$ or $23.72 \%)$. Moreover, most of the teachers (387\% or $76.48 \%$ ) were living with parents during the COVID-19 pandemic. 
As to the emotions of private school teachers, Table 1 reveals the top three emotions felt by teachers during the COVID-19 pandemic. These were the sense of professional and ethical duty in doing their job $(\bar{x}=4.53$, very high), a sense of physical distancing $(\overline{\mathrm{x}}=4.48$, very high), and a sense of obligation and dedication to doing the work as a frontline educator $(\overline{\mathrm{x}}=4.39$, very high $)$. Moreover, emotions such as choosing to stay at home, expecting financial assistance, appreciating monetary compensation and recognition, and feeling of fear and nervousness were also manifested $(\overline{\mathrm{x}}=3.65-4.17$, very high). Results revealed that during the COVID-19 pandemic, private school teachers felt anxious and scared due to susceptibility of infection; as a result, teachers felt the need to follow home quarantine measures. At school work, they felt the professional, ethical, and moral responsibility to perform their functions as educators despite the pandemic situation, thus not quitting their jobs, but highly expect financial support from their employees and government.

\begin{tabular}{|l|c|}
\hline \multicolumn{1}{|c|}{ Emotions during COVID-19 Pandemic } & $\overline{\mathbf{x}}$ (SD) \\
\hline I feel that I still had to do my job as it was my professional and ethical duty & $4.53(0.665)$ \\
\hline $\begin{array}{l}\text { I try limiting my physical contact with other people especially with my co-workers and } \\
\text { parents/students }\end{array}$ & $4.48(1.02)$ \\
\hline I feel that I have the obligation and dedication to do my work as a frontline educator & $4.39(1.33)$ \\
\hline I prefer to work at home than in school during this pandemic & $4.17(1.25)$ \\
\hline I expect financial assistance after the pandemic & $3.90(1.16)$ \\
\hline I appreciate financial compensation I received during the pandemic & $3.87(.853)$ \\
\hline $\begin{array}{l}\text { I appreciate special recognition for my job by the administration and the parents/students I } \\
\text { serve despite the pandemic situation }\end{array}$ & $3.68(1.25)$ \\
\hline I feel nervous and scared & $3.65(.951)$ \\
\hline I feel sad that my workload increased because of the shift to flexible learning & $3.08(1.19)$ \\
\hline I thought of quitting my job due to compensation issues & $1.97(.697)$ \\
\hline
\end{tabular}

Table 1: Emotions of teachers among private higher education institutions (HEIs) during the COVID-19 pandemic ( $\mathrm{n}=506$ ). during school closure and sustained community Concerning the causes of the stress of private school teachers among HEIs during the COVID-19 pandemic,

Table 2 shows that the number one stressor of teachers quarantine is the "No pay or salary cut scheme" implemented by most of the higher academic institutions $(\overline{\mathrm{x}}=4.42$, very high $)$.

\begin{tabular}{|c|c|}
\hline Causes of Stress during COVID-19 Pandemic & $\overline{\mathbf{x}}(\mathrm{SD})$ \\
\hline No pay or low salary for teachers during the COVID-19 pandemic & $4.42(1.04)$ \\
\hline $\begin{array}{l}\text { Watching/reading news on people who VIOLATE the community quarantine and not } \\
\text { staying at home }\end{array}$ & $4.41(1.08)$ \\
\hline Lack of treatment for COVID-19 & $4.31(1.03)$ \\
\hline I could transmit the virus to my family or friends once I got infected & $4.30(1.14)$ \\
\hline $\begin{array}{c}\text { Seeing or knowing that suspected or probable COVID-19 cases are recorded in our local } \\
\text { community }\end{array}$ & $4.25(1.09)$ \\
\hline $\begin{array}{l}\text { Hearing/watching/reading news about the increasing number of confirmed cases and deaths } \\
\text { related to COVID-19 }\end{array}$ & $4.21(0.849)$ \\
\hline Not knowing when the COVID-19 pandemic will be under control & $4.21(0.913)$ \\
\hline $\begin{array}{l}\text { Poor internet connection and lack of ICT equipment for flexible learning, Webinars and } \\
\text { online meetings }\end{array}$ & $4.18(0.870)$ \\
\hline Seeing my colleagues stressed or afraid during the pandemic & $3.94(0.809)$ \\
\hline Conflict between my duty and my own safety & $3.92(0.778)$ \\
\hline The idea of getting tested/screened for COVID infection after exposure & $3.92(0.946)$ \\
\hline I felt there were no adequate Personal Protective Equipment (PPE) for teachers at school & $3.87(1.57)$ \\
\hline Bashes and criticisms against the teachers in the social media during the pandemic & $3.75(1.17)$ \\
\hline Strict community quarantine rules and guidelines which hamper school work and operation & $3.69(1.42)$ \\
\hline Colleagues displaying COVID-like symptoms & $3.68(1.61)$ \\
\hline $\begin{array}{l}\text { I am emotionally exhausted at work especially completing tasks while the community } \\
\text { quarantine is still on-going }\end{array}$ & $3.61(1.15)$ \\
\hline I cannot go home and stay with my family & $3.35(1.01)$ \\
\hline Every time I communicate with parents and students who have school-related concerns & $3.28(1.12)$ \\
\hline $\begin{array}{l}\text { I cannot sleep at night due to nature, demands and concerns, and unexpected changes at } \\
\text { school work }\end{array}$ & $3.09(1.02)$ \\
\hline I have developed respiratory symptoms and feared that I had COVID & $2.79(1.09)$ \\
\hline
\end{tabular}

Table 2: Causes of stress of teachers among private higher education institutions (HEIs) during the COVID-19 pandemic $(\mathrm{n}=506)$.

In terms of teachers' coping strategies during COVID-19 pandemic, Table 3 displays that teachers are following strict personal protective measures $(\overline{\mathrm{x}}=4.90$, very high), read information about COVID-19 ( $\bar{x}=4.74$, very high), avoiding going out in public places to reduce exposure from the virus $(\overline{\mathrm{x}}=4.64$, very high $)$, using virtual/online platforms for school work-related communications $(\overline{\mathrm{x}}=$ 
4.53, very high), communicating with family and friends through social media to seek support $(\overline{\mathrm{x}}=4.52$, very high), talking and motivating oneself positively $(\overline{\mathrm{x}}=$ 4.50 , very high), and keeping busy at home with various activities $(\overline{\mathrm{x}}=4.52$, very high). All of these coping mechanisms, along with other practices reflected in the table, helped private school teachers reduce stress and negative emotions during the COVID-19 pandemic.

\begin{tabular}{|c|c|}
\hline Personal Coping Strategies during COVID-19 Pandemic & $\overline{\mathbf{x}}$ (SD) \\
\hline $\begin{array}{c}\text { Followed strict personal protective measures (e.g., mask, hand washing, social distancing, } \\
\text { etc.) }\end{array}$ & $4.90(0.336)$ \\
\hline Read about COVID-19, its prevention and mechanism of transmission & $4.74(0.503)$ \\
\hline Avoided going out in public places to minimize exposure from COVID-19 & $4.64(1.12)$ \\
\hline Use virtual/online platforms to communicate with my school administrator and co- \\
workers for information and updates & $4.53(0.746)$ \\
\hline Chatted with family and friends to relieve stress and obtain support & $4.52(0.555)$ \\
\hline Talking and motivating myself to face the COVID-19 pandemic with a positive attitude & $4.50(1.23)$ \\
\hline Tried to be busy at home in activities that would keep my mind away from COVID-19 & $4.47(1.23)$ \\
\hline issues & $4.06(0.771)$ \\
\hline Use social media or social networking sites for enjoyment and entertainment (e.g., \\
Facebook, Twitter, Tiktok, YouTube, etc.) & $3.84(0.665)$ \\
\hline Did relaxation activities (e.g., involved in meditations, sports, exercise, etc.) & $3.83(1.47)$ \\
\hline Attend online church, worship and read holy scriptures & $3.67(0.720)$ \\
\hline Attend Online Webinars to continue professional development & $3.36(1.16)$ \\
\hline Avoided doing overtime for school-related works & $2.98(1.19)$ \\
\hline Look for ways to earn extra income during the lockdown (such as online selling, online \\
tutor, etc.)
\end{tabular}

Table 3: Personal coping strategies of teachers among private higher education institutions (HEIs) during the COVID -19 pandemic $(\mathrm{n}=$ 506).

In view of motivational factors of private school teachers for future pandemics, Table 4 reveals that teachers have very high motivation factors to continue their work as educations, even if pandemics will ensue in the future. Data showed that mean ratings of the motivation factors ranged from $\overline{\mathrm{x}}=4.43$ to $\overline{\mathrm{x}}=4.81$ with a very high descriptive level. These motivational factors include health insurance/benefits; school policies on health and safety, prevention and mitigations; provision of ICT resources; effective delivery of flexible learning with the use of Learning Management System (LMS); school administration support and recognition; reduced working hours; government assistance; increased salary; workplace psychiatric help and therapy; collaboration opportunities for schools; and online faculty scholarship.

\begin{tabular}{|c|c|}
\hline Motivational Factors for Future Pandemics & $\overline{\mathbf{x}}$ (SD) \\
\hline Health Insurance/Benefits for Teachers & $4.81(0.663)$ \\
\hline Available cure or vaccine for the disease & $4.79(0.733)$ \\
\hline $\begin{array}{c}\text { spread of the virus } \\
\text { School's policies on health and safety protocols on the prevention and mitigation of the }\end{array}$ & $4.75(0.645)$ \\
\hline Provision of ICT materials and internet connectivity for teachers & $4.75(0.724)$ \\
\hline $\begin{array}{c}\text { Preparedness/Training of teachers and students on Flexible learning using online } \\
\text { modalities }\end{array}$ & $4.73(0.690)$ \\
\hline Clear and comprehensive policies, system and guidelines for flexible learning & $4.71(0.946)$ \\
\hline School administration support for teachers & $4.71(0.807)$ \\
\hline Government support for teachers & $4.67(0.768)$ \\
\hline Use of a Learning Management System for Online Teaching & $4.64(0.891)$ \\
\hline Reduced working hours during virus outbreaks & $4.58(0.969)$ \\
\hline Collaboration Opportunities for schools & $4.57(0.649)$ \\
\hline Increase of Salary for Teachers & $4.53(0.849)$ \\
\hline $\begin{array}{c}\text { anxiety } \\
\text { Online Faculty Scholarship }\end{array}$ & $4.51(0.928)$ \\
\hline Psychiatric help and therapy made available in the workplace to help reduce stress and & $4.50(0.817)$ \\
\hline antion from management and supervisor for teachers' extra efforts & $4.43(0.740)$ \\
\hline
\end{tabular}

Table 4: Motivational factors of teachers among private higher education institutions (HEIs) to encourage continuation of work in future pandemics $(n=506)$.

Moreover, Figure 1 shows the link of stressors, coping strategies, and motivational factors to the emotions of teachers among HEIs during COVID-19 pandemic. Data revealed that stressors were correlated to the emotions of teachers $(r$-value $=0.250 ; p$-value $=0.010) ;$ while coping strategies were also correlated to teachers' 
emotions $(r$-value $=0.328 ; p$-value $=0.001)$. Also, teachers' motivational factors were correlated with their emotions during the COVID-19 pandemic ( $r$-value $=$ 0.348; $p$-value $=0.000$ ). Correlation results implied that high level of stressors of teachers during the pandemic influences both positive and negative emotions towards the community and work situations. As they increasingly practice varied coping strategies and augment motivation to continue to work despite the situation, the better emotional state with lesser adverse feelings they will have.

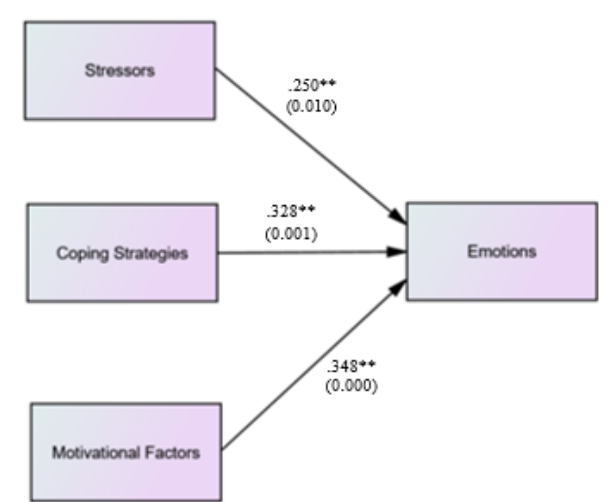

Figure 1: The link of stressors, coping strategies, and motivational factors to emotions of teachers among private Higher Education Institutions (HEIs) during the COVID-19 pandemic. Note: ${ }^{* *}$ : Correlation is significant at 0.01 level (2tailed).

\section{DISCUSSION}

Amid COVID-19 pandemic situation, teachers among private Higher Education Institutions (HEIs) in Southern Philippines still strive to sustain quality delivery of teaching and learning to students and attain school quality objectives despite psychological challenges brought about the socio-economic and health crisis. Based on the findings of the study, private school teachers experience anxiety or psychological stress during the COVID-19 pandemic, but kept maintaining their commitment to their individual and collective functions in their educational institutions considering professional, ethical, and moral responsibility towards their profession. This confirmed the findings of the study of Talidong \& Toquero [3], which stated that Filipino teachers felt the anxiety or psychological stress brought by COVID-19. They felt afraid that their family members might be infected with COVID-19. Also, it affirmed the contention of various authors [8-10] which explained that during epidemics, employees might expect extra compensation, and special recognition. However, Khalid et al. [7] had pointed out that during virus outbreaks, the sense of ethical and professional obligation towards their profession is a significant feeling that inspires workers to perform job functions.

Moreover, the primary stressor of the private school teachers among HEIs was the "No pay or salary cut scheme." For this reason, the majority of the teachers expected financial support from the school administration and government because of the crisis. This is due to the decreased number of enrolment of students and limited financial operations of the schools. Private education sectors in the Philippines are seeking support for private school teachers who are affected by the pandemic [11]. Relative to this finding, Elhais [12] explained that teachers in the United Arab Emirates (UAE) have told of pressure to accept lower salaries or unpaid leave due to the coronavirus pandemic. Private-sector employers responding to the pandemic are entitled to make adjustments to their working practices to keep their businesses going. Options include implementing remote working and temporarily or permanently reducing staff salaries.

Nonetheless, teachers utilized personal coping strategies to deal with stress and adverse emotions such as adhering to stringent community quarantine measures, updating oneself about COVID-19 situation in the community, maintaining communication with workmates, family, and friends, and boosting positive mind-set. As mentioned by previous authors who investigated about coping strategies during pandemic [2,7,13], stringent personal protective measures such as reduced community exposure are significant. Besides, Schiavo, May Leung, \& Brown [14] said that in times of pandemic, workplaces 
should, therefore, focus on improved communication and provision of psychological support to employees to reduce stressful experiences.

In this study, various motivational factors were also perceived as significant efforts to be implemented when dealing with future pandemics in the field of academics. Private school teachers recognized the importance of having improved health benefits, Occupational Safety and Health Standards (OSHS), educational technologies, collaboration, teachers' salaries, professional development and growth opportunities, and mental health programs for teachers among HEIs. In support, UNESCO [15] contemplated that there is a need to support educational institutions in their efforts to mitigate the immediate impact of school closures, particularly for more vulnerable and disadvantaged communities since most governments around the world have temporarily closed educational institutions in an attempt to contain the spread of the COVID-19 pandemic.
The stressors of teachers during the pandemic influence their emotions towards the community and work situations. As they increasingly practice varied coping strategies and augment motivation to continue to work despite the situation, the better emotional state with lesser adverse feelings they will have. This confirmed the contention of the Center of Disease and Control Prevention [16] which stated that the COVID-19 may be stressful for people and cause strong emotions in adults. Further, Folkman \& Lazarus [17] explained that people use coping strategies to manage their emotions by applying and organizing thoughts and behaviors towards decreasing stressors. Also, Sincero [18] had pointed out in her article that emotions could be viewed as a result of a specific motivated behavior. Data suggested that the government must strengthen support to teachers, especially among private educational institutions, in their efforts to continue delivering quality teaching in higher education. It is necessary to address stress-related problems of teachers during the pandemic, and help them strengthen their coping practices and motivation at work.

\section{REFERENCES}

1. International Association of Universities (2020) Covid-19: Higher education challenges and responses.

2. Baloran ET (2020) Knowledge, attitudes, anxiety, and coping strategies of students during COVID-19 pandemic. Journal of Loss and Trauma: 1-8.

3. Talidong KJB, Toquero CMD (2020) Philippine teachers' practices to deal with anxiety amid COVID-19. Journal of Loss and Trauma: $1-7$.

4. Zhao Y, An Y, Tan X, et al. (2020) Mental health and its influencing factors among self-isolating ordinary citizens during the beginning epidemic of COVID-19. Journal of Loss and Trauma: 1-14.

5. Pan H (2020) A glimpse of university students' family life amidst the COVID-19 virus. Journal of Loss and Trauma: 14.

6. Li C, Lalani F (2020) The COVID-19 pandemic has changed education forever. This is how.

7. Khalid I, Khalid T, Qabajah M, et al. (2016) Healthcare workers emotions, perceived stressors and coping strategies during a MERS-CoV outbreak. Clinical Medicine \& Research 14(1): 7-14.

8. Baumann AO, Blythe JM, Underwood JM (2006) Surge capacity and casualization. Canadian Journal of Public Health 97(3): 230-232.

9. Lee SH, Juang YY, Su YJ, et al. (2005) Facing SARS: Psychological impacts on SARS team nurses and psychiatric services in a Taiwan general hos pital. General Hospital Psychiatry 27(5): 352-358. 
http://www.tridhas cholars .org | December-2020

10. Ly T, Selgelid MJ, Kerridge I (2007) Pandemic and public health controls: Toward an equitable compensation system. Journal of Law and Medicine 5: 296-302.

11. Hernando-Malipot M (2020) DepEd seeks aid for private school teachers affected by COVID-19 crisis. Manila Bulletin.

12. Elhais H (2020) Teachers facing job loss amid coronavirus may have grounds for damages.

13. Faye O, Boëlle PY, Heleze E, et al. (2015) Chains of transmission and control of Ebola virus disease in Conakry, Guinea, in 2014: An observational study. The Lancet Infectious Diseases 15(3): 320-326.

14. Schiavo R, May Leung M, Brown M (2014) Communicating risk and promoting disease mitigation measures in epidemics and emerging disease settings. Pathogens and Global Health 108(2): 76-94.

15. UNESCO (2020) School closures caused by coronavirus (Covid-19).

16. Center of disease and control prevention (2020) Coping with stress.

17. Folkman S, Lazarus RS (1980) An analysis of coping in a middle-aged community sample. Journal of Health and Social Behavior 21: 219-232.

18. Sincero SM (2020) Motivation and emotion. 